\title{
Aplikasi Health Belief Model Pada Penanganan Kegawatdaruratan Anak Dengan Kejang Demam Di Rumah
}

\author{
Tri Widyastuti Handayani ${ }^{1}$, Dyah Dwi Astuti ${ }^{*}$, Duwi Pudji Astuti ${ }^{3}$ \\ ${ }^{1}$ Poltekkes Kemenkes Yogyakarta, ${ }^{2,3}$ Poltekkes Kemenkes Surakarta \\ *Email: astutidyah83@poltekkes-solo.ac.id
}

\begin{abstract}
Background: A febrile seizure have negative impacts for children and parents if mismanagement. A febrile seizure in children of disorder causing fear of cognitive development and achievement in their school as increase the risk of attention deficit hyperactifity disorder (ADHD). The purpose of this community service activity is to improve knowledge and skills on the emergency management of feverconvulsed children at home with the Health Belief Model approach. Methods: Community service activities are conducted through education and small group discussions are created by facilitators. Results: The result of this community service activities showed the increased the value of test weighted pre (65) and post (80). Increased knowledge parents as first responder in children with febrile seizure are needed to increade the ability home emergency first aid for children having a febrile seizure. Conclusion: Community service activities was applied the evidence based practice of health belief model in home emergency first aid for children having a febrile seizure.
\end{abstract}

Keywords: community roles; community service; febrile seizure

\section{PENDAHULUAN}

Kejang demam merupakan kejadian kejang yang umum terjadi pada anak usia di bawah lima tahun. Kejang demam berhubungan dengan peningkatan suhu tubuh lebih dari $38^{\circ} \mathrm{C}$ pada anak, serta tidak disebabkan oleh infeksi sistem persarafan pusat, gangguan metabolisme tubuh, dan tanpa riwayat kejang sebelumnya (Laino, Mencaroni, \& Esposito, 2018). Kejadian kejang demam diperkirakan sekitar 6-15\% pada anak usia antara 6 bulan sampai dengan 5 tahun, serta sekitar 30\% terjadi kejang berulang. Kejadian kejang demam meningkat pada anak usia 18 bulan (Srinivasa, Anjum, Patel, S., \& G., 2018). Kejadian kejang demam kompleks sekitar 30-35\% dengan klasififikasi kejang fokal, durasi lebih dari 10 menit, kejang berulang dalam 24 jam (Gundapu, Bhavani, Kiran, \& Kumar, 2017).

Kejang demam tidak meningkatkan risiko kematian pada anak, namum menimbulkan dampak negatif bagi anak dan orang tua jika tidak ditangani secara tepat. Kejang demam pada anak menimbulkan ketakutan akan terjadinya gangguan perkembangan kognitif dan prestasi di sekolah (Ateşoğlu, İnce, Lüleci, Ergör, \& Aydın, 2018). Hasil penelitian yang dilakukan oleh Salehi et al. (2016) menunjukkan bahwa anak dengan kejang demam meningkatkan risiko terjadinya hyperactive impulsive (HI) yang merupakan tanda dan gejala pada anak dengan attention deficit hyperactivity disorder (ADHD). Peningkatan risiko tersebut disebabkan oleh pengetahuan orang tua, dukungan keluarga, serta kemampuan dalam penanganan kejang demam pada anak yang rendah.

Kejang demam pada anak juga berdampak pada orang tua. Kejang demam merupakan pengalaman yang menimbulkan trauma tersendiri pada orang tua. Kejang demam dapat meningkatkan kecemasan dan ketakutan bagi orang tua. Orang tua beranggapan bahwa kejang demam pada anak dapat menyebabkan kerusakan otak, menular ke saudara kandung, gangguan perkembangan, berulang selama hidup anak dan menimbulkan kematian (Hamaad, Hassan, \& Alseraty, 2019). Hasil penelitian yang 
dilakukan oleh Sajadi dan Khosravi (2017) menunjukkan bahwa mayoritas orang tua tidak mengetahui cara penanganan kegawatdaruratan kejang demam pada anak, sehingga menimbulkan perilaku yang dapat berakibat negatif dalam penanganan anak dengan kejang demam. Perilaku tersebut antara lain memberikan minuman saat anak kejang akan meningkatkan terjadinya risiko aspirasi, memberikan kompres dingin pada anak, dan orang tua tidak mempunyai termometer di rumah (Srinivasa et al., 2018).

Pertolongan kegawatdaruratan di rumah pada anak dengan kejang demam menentukan hasil keluaran kesehatan pada anak. Pendidikan kesehatan dan peningkatan kemampuan orang tua sebagai first responder (penolong pertama) dalam penanganan kegawatdaruratan anak dengan kejang demam di rumah diperlukan untuk menghasilkan keluaran yang optimal (Chiabi et al., 2018). Peningkatan pengetahuan orang tua meliputi konsep tentang kejang demam, hubungan antara demam dan kejang, apa yang boleh dan tidak boleh dilakukan untuk penanganan kegawatdaruratan anak dengan kejang demam di rumah. Peningkatan kemampuan orang tua berfokus pada kemampuan orang tua bersikap tenang, bagaimana cara mengukur suhu tubuh dengan termometer, bagaimana melakukan tepid sponge, serta pemberian dosis obat antipiretik dan antikonvulsan (Silverman et al., 2017).

Hasil penelitian lainnya dilakukan oleh Dogahe et al. (2018) bertujuan untuk mengetahui pengaruh pemberian edukasi dengan pendekatan health belief model (HBM) dalam perilaku pencegahan kejang demam pada anak. Pengumpulan data dilakukan dengan pengisian kuesioner yang menggunakan pendekatan HBM Hasil penelitian menunjukkan Edukasi dengan menggunakan pendekatan HBM dapat meningkatkan pengetahuan dan kemampuan orang tua dalam penanganan kegawatdaruratan anak dengan kejang demam di rumah. Hasil evidence based practice tersebut melatarbelakangi pelaksanaan kegiatan pengabdian masyarakat. Kegiatan pengabdian masyarakat ini berfokus pada peningkatan kemampuan orang tua dalam penanganan kegawatdaruratan anak dengan kejang demam di rumah. Aplikasi teori yang digunakan adalah HBM yang meliputi enam komponen antara lain perceived susceptibility, perceived severity, perceived benefits, perceived barriers, cues to action, dan self efficacy (Pender, Murdaugh, \& Parsons, 2015).

\section{TINJAUAN PUSTAKA}

Kejang demam adalah bangkitan kejang yang dapat terjadi pada anak berumur 6 bulan sampai 5 tahun yang mengalami kenaikan suhu tubuh (suhu diatas $38^{\circ} \mathrm{C}$ ) yang tidak disebabkan oleh proses intracranial. Kejang demam memiliki prognosis yang baik, namun sekitar 30 sampai 35\% anak dengan kejang demam pertama akan mengalami kejang demam berulang.2,3 Setiap tahunnya kejadian kejang demam di USA Hampir 1,5 juta, dan sebagian besar terjadi dalam rentang usia 6 hingga 36 bulan, dengan puncak pada usia 18 bulan (Rasyid, Kusuma, Vita, \& Purba, 2019).

Penyebab kejang demam hingga kini belum di ketahui dengan pasti. Kejang demam tidak selalu timbul pada suhu yang tinggi, kadang kadang demam tidak terlalu tinggi dapat menyebabkan kejang. Adapun penyebab terjadinya kejang demam, antara lain : obat-obatan, ketidakseimbangan kimiawi seperti hiperkalemia, hipoglikemia dan asidosis, demam, patologis otak, dan eklamsia (Rasyid et al., 2019).

\section{DESAIN PENELITIAN}

Kegiatan pengabdian masyarakat ini termasuk dalam Skema Program Kemitraan Masyarakat (PKM) yang merupakan program pengabdian kepada masyarakat yang 
bermitra dengan masyarakat di bidang kesehatan. Tujuan pada skema ini adalah mengaplikasikan hasil penelitian berdasarkan evidence based practice penanganan kegawatdaruratan anak dengan kejang demam di rumah. Mitra pengabdian kepada masyarakat dengan skema PKM antara lain Puskesmas Sibela, kader masyarakat, tokoh masyarakat dan tokoh agama, ibu-ibu Pemberdayaan Kesejahteraan Keluarga (PKK), dan kelompok masyarakat seperti ibu dengan anak usia bawah lima tahun.

Kegiatan pengabdian masyarakat ini dilaksanakan di Posyandu Sejahtera RW IV Kelurahan Mojosongo Wilayah Kerja Puskesmas Sibela. Pembekalan kader dilakukan pada tanggal 18 September 2020; sedangkan penyuluhan dilakukan ibu-ibu anggota PKK dilakukan pada tanggal 19 September 2020. Kegiatan pengabdian masyarakat dalam rangka penanganan kegawatdaruratan anak dengan kejang demam di rumah. Tahapan atau prosedur yang dilakukan kegiatan tersebut meliputi tahap persiapan, tahap pelaksanaan, dan tahap evaluasi.

Tahap persiapan meliputi kegiatan penyusunan proposal pengabdian masyarakat, pembuatan modul, mengurus perijinan dari pemangku kepentingan, penjajagan dan melakukan koordinasi dengan pihak Puskesmas Sibela pada bulan Februari-Juni 2020. Pada tahap pelaksanaan yaitu setelah mendapatkan ijin dari institusi pendidikan maupun wilayah setempat. Pada tahap pelaksanaan dibagi menjadi 2 tahap yaitu pembekalan kader Posyandu Sejahtera RW IV Kelurahan Mojosongo dan penyuluhan ibu-ibu PKK RW IV Kelurahan Mojosongo. Pada saat pelaksanaan edukasi juga peserta dikelompokkan menjadi kelompok-kelompok kecil untuk diskusi (small group discussion) yang didampingi oleh fasilitator. Pelaksanaan kegiatan pengabdian masyarakat dengan memberikan edukasi tentang penanganan kegawatdaruratan anak dengan kejang demam di rumah meliputi:

a. Modul I: berisi konsep tentang kejang demam antara lain tipe kejang demam umum (tonik-klonik, atonia), kejang kompleks (fokal dan durasi lebih dari 15 menit, dapat berulang dalam 24 jam), melihat tipe kejang tersebut dengan video, menjelaskan dampak dari kejang demam.

b. Modul II: berisi manajemen penanganan kejang demam yang tepat melalui presentasi. c. Modul III: berisi pengalaman orang tua mengenai reaksi orang tua terhadap kejang demam, penyebab, risiko kejang berulang, dan penanganan pertama anak dengan kejang demam.

Pada tahap evaluasi yaitu melakukan evaluasi pelaksanaan kegiatan edukasi dengan melakukan pengisian kuesioner (Lampiran 1.). Kuesioner tersebut merupakan penerapan teori HBM berdasarakan analisis evidence based practice. Kuesioner terdapat bagian pertanyaan tentang perceived susceptibility (kerentanan), perceived severity (keparahan), perceived benefits (manfaat), dan perceived barriers (hambatan). Evaluasi dengan melakukan penilaian pada kuesioner tersebut pre dan post pemberian edukasi, kemudian membandingkan antara keduanya. Rencana tindak lanjut dari kegiatan pengabdian masyarakat dengan menjalin kemitraan dengan Puskesmas Sibela adalah penggunaan modul penanganan kegawatdaruratan anak dengan kejang demam di rumah sebagai pedoman untuk melakukan program edukasi terstruktur di wilayah kerja Puskesmas Sibela yang lainnya.

\section{HASIL PENELITIAN}

Hasil pelaksanaan kegiatan pengabdian masyarakat meliputi pemberian edukasi terstruktur dengan pendekatan HBM kepada kelompok kunci seperti puskesmas, kader kesehatan, tokoh agama, tokoh masyarakat, ibu-ibu PKK, dan orang tua yang 
mempunyai anak usia bawah lima tahun. pemberian edukasi terstruktur dengan pendekatan HBM melalui media yang digunakan adalah modul yang berisi tentang konsep kejang demam, manajemen penanganan kejang demam, dan pengalaman orang tua mengenai reaksi orang tua terhadap kejang demam. Edukasi dan evaluasi untuk kegiatan dilakukan dengan melakukan pengisian kuesioner. Evaluasi dengan melakukan penilaian pada kuesioner tersebut pre dan post pemberian edukasi, kemudian membandingkan antara keduanya. Kuesioner terdapat bagian pertanyaan tentang perceived susceptibility (kerentanan), perceived severity (keparahan), perceived benefits (manfaat), dan perceived barriers (hambatan).

Tabel 1. Hasil Pre Tes Kader Posyandu Sejahtera pada Kegiatan Pengabdian Masyarakat di RW IV Kelurahan Mojosongo Kota Surakarta $(n=6)$

\begin{tabular}{|c|c|c|c|}
\hline Pertanyaan & & Frekuensi & $\begin{array}{c}\text { Prosentase } \\
(\%)\end{array}$ \\
\hline $\begin{array}{l}\text { Kejang demam merupakan kejang yang terjadi } \\
\text { pada anak yang mengalami infeksi pada otak. }\end{array}$ & $\begin{array}{l}\text { Salah } \\
\text { Benar }\end{array}$ & $\begin{array}{l}1 \\
5\end{array}$ & $\begin{array}{l}16.7 \\
83.3\end{array}$ \\
\hline $\begin{array}{l}\text { Peningkatan risiko kejang demam terjadi pada } \\
\text { anak yang mengalami infeksi saluran nafas, } \\
\text { berusia kurang dari } 6 \text { tahun, dan mempunyai } \\
\text { faktor keturunan. }\end{array}$ & $\begin{array}{l}\text { Salah } \\
\text { Benar }\end{array}$ & $\begin{array}{l}1 \\
5\end{array}$ & $\begin{array}{l}16.7 \\
83.3\end{array}$ \\
\hline $\begin{array}{l}\text { Kejang demam kompleks adalah kejang fokal } \\
\text { (satu sisi tubuh) yang berulang dalam } 24 \text { jam. }\end{array}$ & $\begin{array}{l}\text { Salah } \\
\text { Benar }\end{array}$ & $\begin{array}{l}3 \\
3\end{array}$ & $\begin{array}{l}50 \\
50\end{array}$ \\
\hline $\begin{array}{l}\text { Kejang demam sederhana lebih tinggi risiko } \\
\text { terjadinya epilepsi dibandingkan dengan kejang } \\
\text { demam kompleks. }\end{array}$ & $\begin{array}{l}\text { Salah } \\
\text { Benar }\end{array}$ & $\begin{array}{l}1 \\
5\end{array}$ & $\begin{array}{l}16.7 \\
83.3\end{array}$ \\
\hline $\begin{array}{l}\text { Anak yang sedang mengalami kejang demam } \\
\text { dapat diberikan sendok atau kasa atau kain di } \\
\text { mulut untuk menghindari lidah tergigit. }\end{array}$ & $\begin{array}{l}\text { Salah } \\
\text { Benar }\end{array}$ & - & $\begin{array}{c}- \\
100\end{array}$ \\
\hline $\begin{array}{l}\text { Saat anak sedang terjadi kejang segera berikan } \\
\text { minuman manis atau madu. }\end{array}$ & $\begin{array}{l}\text { Salah } \\
\text { Benar }\end{array}$ & $\begin{array}{l}3 \\
3\end{array}$ & $\begin{array}{l}50 \\
50\end{array}$ \\
\hline $\begin{array}{l}\text { Amankan lingkungan selama anak terjadi kejang } \\
\text { demam. }\end{array}$ & $\begin{array}{l}\text { Salah } \\
\text { Benar }\end{array}$ & $\begin{array}{l}1 \\
5\end{array}$ & $\begin{array}{l}16.7 \\
83.3\end{array}$ \\
\hline $\begin{array}{l}\text { Kompres dingin dapat mencegah terjadinya } \\
\text { kejang demam pada anak. }\end{array}$ & $\begin{array}{l}\text { Salah } \\
\text { Benar }\end{array}$ & $\begin{array}{l}2 \\
4\end{array}$ & $\begin{array}{l}33.3 \\
66.7\end{array}$ \\
\hline $\begin{array}{l}\text { Kompres hangat dapat dilakukan di bagian } \\
\text { lipatan tubuh seperti leher, ketiak, dan lipatan } \\
\text { paha. }\end{array}$ & $\begin{array}{l}\text { Salah } \\
\text { Benar }\end{array}$ & - & $\begin{array}{c}- \\
100\end{array}$ \\
\hline $\begin{array}{l}\text { Peran kader di masyarakat adalah mendeteksi } \\
\text { dini keluarga dengan anak yang berisiko } \\
\text { terjadinya kejang demam. }\end{array}$ & $\begin{array}{l}\text { Salah } \\
\text { Benar }\end{array}$ & - & - \\
\hline
\end{tabular}


Pada Tabel 1. mendeskripsikan tentang hasil pre tes kader kesehatan tentang kejang demam pada anak. Sepuluh pertanyaan terdiri dari pertanyaan tentang perceived susceptibility (kerentanan), perceived severity (keparahan), perceived benefits (manfaat), dan perceived barriers (hambatan). Hasil menunjukkan bahwa mayoritas kader kesehatan belum mengetahui tentang kejang demam terutama pada definisi, penyebab, dan penanganan kejang demam pada anak.

Kejang demam merupakan pengalaman yang menimbulkan trauma tersendiri pada orang tua. Kejang demam dapat meningkatkan kecemasan dan ketakutan bagi orang tua. Orang tua beranggapan bahwa kejang demam pada anak dapat menyebabkan kerusakan otak, menular ke saudara kandung, gangguan perkembangan, berulang selama hidup anak dan menimbulkan kematian. Orang tua mayoritas mempunyai persepsi bahwa kejang demam disebabkan oleh demam dan demam diakibatkan oleh infeksi virus atau bakteri (Villarejo-Rodríguez \& Rodríguez-Martín, 2020). Kejang demam mempunyai dampak negatif pada orang tua seperti gangguan tidur, gangguan interaksi sosial, dan waktu bekerja.

Perilaku tersebut antara lain memberikan minuman saat anak kejang akan meningkatkan terjadinya risiko aspirasi, memberikan kompres dingin pada anak, dan orang tua tidak mempunyai termometer di rumah (Castellano, Talamona, Giglio, Sabbaj, $\&$ Gentile, 2020). Orang tua direkomendasikan untuk waspada jika anak mengalami demam karena akan meningkatkan risiko terjadinya kejang demam (Alqahtani, 2019).

Tabel 2. Hasil Post Tes Kader Posyandu Sejahtera pada Kegiatan Pengabdian Masyarakat di RW IV Kelurahan Mojosongo Kota Surakarta $(n=6)$

\begin{tabular}{|c|c|c|c|}
\hline \multicolumn{2}{|l|}{ Pertanyaan } & Frekuensi & $\begin{array}{c}\text { Prosentase } \\
(\%)\end{array}$ \\
\hline \multirow{2}{*}{$\begin{array}{l}\text { Kejang demam merupakan kejang yang terjadi } \\
\text { pada anak yang mengalami infeksi pada otak. }\end{array}$} & Salah & 1 & 16.7 \\
\hline & Benar & 5 & 83.3 \\
\hline \multirow{2}{*}{$\begin{array}{l}\text { Peningkatan risiko kejang demam terjadi pada } \\
\text { anak yang mengalami infeksi saluran nafas, } \\
\text { berusia kurang dari } 6 \text { tahun, dan mempunyai } \\
\text { faktor keturunan. }\end{array}$} & Salah & 1 & 16.7 \\
\hline & Benar & 5 & 83.3 \\
\hline \multirow{2}{*}{$\begin{array}{l}\text { Kejang demam kompleks adalah kejang fokal } \\
\text { (satu sisi tubuh) yang berulang dalam } 24 \text { jam. }\end{array}$} & Salah & - & - \\
\hline & Benar & 6 & 100 \\
\hline \multirow{2}{*}{$\begin{array}{l}\text { Kejang demam sederhana lebih tinggi risiko } \\
\text { terjadinya epilepsi dibandingkan dengan kejang } \\
\text { demam kompleks. }\end{array}$} & Salah & 2 & 33.3 \\
\hline & Benar & 4 & 66.7 \\
\hline \multirow{2}{*}{$\begin{array}{l}\text { Anak yang sedang mengalami kejang demam } \\
\text { dapat diberikan sendok atau kasa atau kain di } \\
\text { mulut untuk menghindari lidah tergigit. }\end{array}$} & Salah & 6 & 100 \\
\hline & Benar & - & - \\
\hline \multirow{2}{*}{$\begin{array}{l}\text { Saat anak sedang terjadi kejang segera berikan } \\
\text { minuman manis atau madu. }\end{array}$} & Salah & 6 & 100 \\
\hline & Benar & - & - \\
\hline Amankan lingkungan selama anak terjadi kejang & Salah & - & - \\
\hline
\end{tabular}




\begin{tabular}{|c|c|c|c|}
\hline \multicolumn{2}{|l|}{ Pertanyaan } & Frekuensi & $\begin{array}{c}\text { Prosentase } \\
(\%)\end{array}$ \\
\hline demam. & Benar & 6 & 100 \\
\hline Kompres dingin dapat mencegah terjadinya & Salah & 5 & 16.7 \\
\hline kejang demam pada anak. & Benar & 1 & 83.3 \\
\hline $\begin{array}{l}\text { Kompres hangat dapat dilakukan di bagian } \\
\text { lipatan tubuh seperti leher, ketiak, dan lipatan } \\
\text { paha. }\end{array}$ & $\begin{array}{l}\text { Salah } \\
\text { Benar }\end{array}$ & - & $\begin{array}{c}- \\
100\end{array}$ \\
\hline $\begin{array}{l}\text { Peran kader di masyarakat adalah mendeteksi } \\
\text { dini keluarga dengan anak yang berisiko } \\
\text { terjadinya kejang demam. }\end{array}$ & $\begin{array}{l}\text { Salah } \\
\text { Benar }\end{array}$ & - & $\begin{array}{c}- \\
100\end{array}$ \\
\hline
\end{tabular}

Pada Tabel 2. mendeskripsikan tentang hasil post tes kader Kesehatan setelah dilakukan edukasi. Sepuluh pertanyaan mengandung tentang perceived susceptibility (kerentanan), perceived severity (keparahan), perceived benefits (manfaat), dan perceived barriers (hambatan). Hasil menunjukkan bahwa mayoritas kader kesehatan memahami tentang definisi, penyebab, dan penanganan kejang demam di rumah.

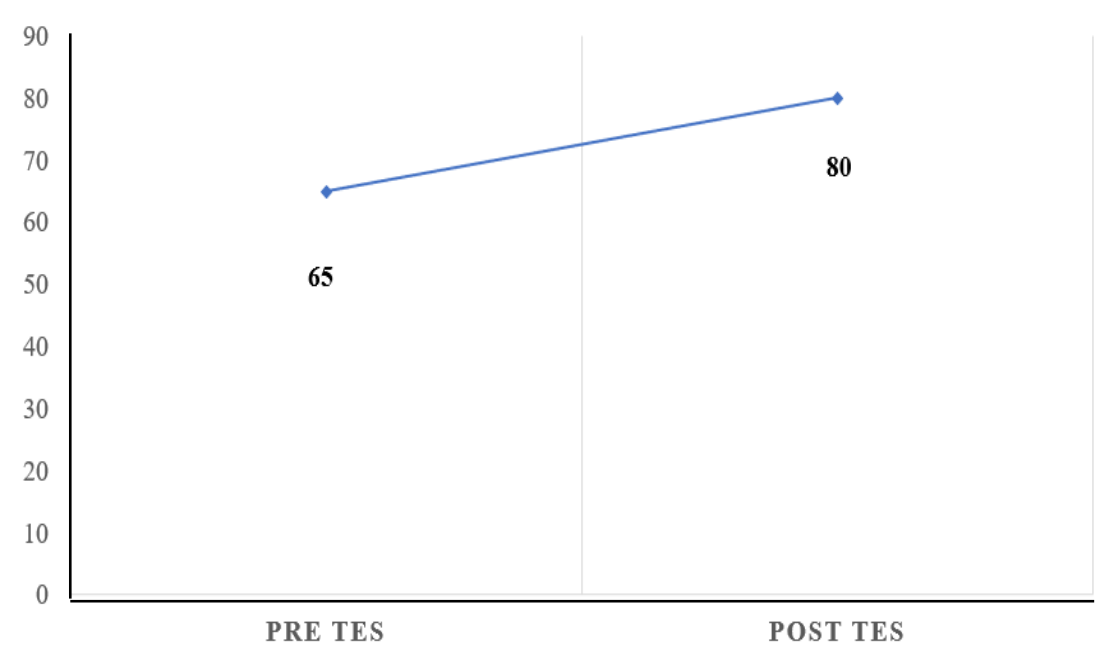

Gambar 1. Hasil Rerata Pre dan Post Tes Kader Posyandu Sejahtera pada Kegiatan Pengabdian di RW IV Kelurahan Mojosongo Kota Surakarta $(n=6)$

Gambar 1. mendeskripsikan hasil rerata pre dan post tes kader Posyandu Sejahtera. Hasil kegiatan pengabdian masyarakat yang diikuti oleh 6 kader Posyandu Sejahtera. Hasil evaluasi menunjukkan terjadi peningkatan rerata nilai pre tes 65 menjadi nilai post tes 80 dengan rentang nilai 0-100. Hasil kegiatan pengabdian masyarakat ini didukung oleh penelitian randomized clinical trial oleh Dogahe et al. (2018) yang bertujuan untuk mengetahui pengaruh pemberian pendidikan kesehatan berdasarkan health belief model pada ibu dalam perilaku pencegahan kejang demam pada anak. Ibu yang mempunyai anak berusia 6 bulan sampai dengan 3 tahun berjumlah 200 orang yang dikelompokkan menjadi kelompok intervensi dan kontrol.

Pengumpulan data dilakukan dengan pengisian kuesioner yang menggunakan pendekatan health belief model. Pendidikan kesehatan dengan menggunakan health 
belief model dapat meningkatkan pengetahuan dan kemampuan ibu dalam pencegahan terjadinya permasalahan kesehatan pada anak (Adriani, Astuti, \& ..., 2020).

\section{PEMBAHASAN}

Penelitian oleh Kumar et al. (2019) melakukan evaluasi keefektifan pemberian pendidikan kesehatan terstruktur dengan edukasi melalui pamflet terhadap pengetahuan ibu dalam penanganan anak dengan kejang. Ibu yang mempunyai anak usia 1-18 tahun yang mengalami kejang minimal 1 kali. Subyek penelitian dibagi menjadi 2 kelompok intervensi dan kelompok kontrol. Evaluasi dilakukan dengan kuesioner terstruktur dalam pertolongan pertama anak dengan kejang di rumah. Pemberian edukasi terstruktur efektif meningkatkan pengetahuan pengasuh dalam penanganan anak dengan kejang.

Pemberian edukasi melalui pamflet saja tidak meningkatkan pengetahuan anak dengan kejang. Edukasi terstrutur efektif untuk dilakukan di negara berkembang dalam penanganan anak dengan kejang demam. Penelitian lainnya oleh Barzegar et al. (2016) bertujuan untuk membandingkan pengaruh strategi edukasi dengan menulis dan menulis disertai dengan instruksi verbal terhadap pengetahuan, sikap, dan perilaku dalam penanganan anak dengan kejang demam. Ibu dengan anak kejang demam sejumlah 102 anak. Penelitian terdiri dari tiga kelompok antara lain kelompok I kontrol yang tidak diberikan intervensi, kelompok II kelompok intervensi dengan pumphlet, kelompok III kelompok intervensi pamflet dan instruksi verbal.

Pemberian edukasi dengan metode pamflet dan pamflet dengan instruksi verbal dapat meningkatkan pengetahuan, sikap, dan perilaku ibu dalam penanganan anak dengan kejang demam. Hasil kegiatan pengabdian masyarakat juga didukung oleh Elbilgahy dan Abd El Aziz (2017) melakukan evaluasi pengaruh pemberian edukasi terhadap pengetahuan ibu dan sikap dalam penanganan anak dengan kejang demam di rumah. Subyek penelitian adalah ibu dengan anak yang mengalami kejang demam pertama kali atau berulang dengan usia 6 bulan sampai dengan 5 tahun. Pendidikan kesehatan berpengaruh positif terhadap pengetahuan ibu, sikap dan manajemen penanganan anak dengan kejang demam di rumah.

Penelitian Kizılay et al. (2017) mengidentifikasi kebutuhan orang tua dalam penanganan anak dengan kejang demam. Peneliti menganalisis pengaruh pemberian edukasi terhadap tingkat kecemasan orang tua anak dengan kejang demam. Subyek penelitian adalah 172 orang tua yang mempunyai anak yang dirawat di ruang gawat darurat, ruang rawat inap, klinik rawat jalan, dan ruang khusus persarafan anak. Sejumlah 113 anak dimasukkan dalam kelompok intervensi dan 59 anak kelompok kontrol. Intervensi berupa pemberian edukasi pada keluarga selama 30 menit dengan modul sebagai berikut: Modul I: tipe kejang antara lain umum (tonik-klonik, atonia), kejang kompleks (fokal dan durasi lebih dari 15 menit, dapat berulang dalam 24 jam), melihat tipe kejang tersebut dengan video, menjelaskan dampak dari kejang demam. Modul II: berisi manajemen penanganan kejang demam yang tepat melalui presentasi. Modul III: berisi pengalaman orang tua mengenai reaksi orang tua terhadap kejang demam, penyebab, risiko kejang berulang, dan penanganan pertama anak dengan kejang demam. Pemberian edukasi melalui media modul efektif menurunkan kecemasan orang tua dalam penanganan anak kejang demam.

Penelitian lainnya menganalisis pengaruh pemberian paket edukasi terhadap kecemasan ibu anak dengan kejang demam. Ibu dengan anak kejang demam sejumlah 81 orang yang dibagi menjadi kelompok kontrol 41 orang dan kelompok intervensi 
sejumlah 40 orang. Evaluasi dilakukan dengan State Anxiety Inventory in Indonesian version. Pemberian paket edukasi dapat menurunkan kecemasan anak dengan kejang demam (Rofiqoh \& Isyti'aroh, 2018).

Kegiatan pengabdian masyarakat ini memiliki kelebihan pemberian edukasi yang terstruktur dengan menerapkan Health Belief Model yang terdiri dari pengetahuan kognitif, afektif, dan ketrampilan pencegahan kejang demam pada anak. Keberlanjutan dari kegiatan pengabdian masyarakat ini adalah dapat diterapkan di wilayah kerja Puskesmas Sibela lainnya dengan menerapkan edukasi terstruktur dan pendekatan Health Belief Model.

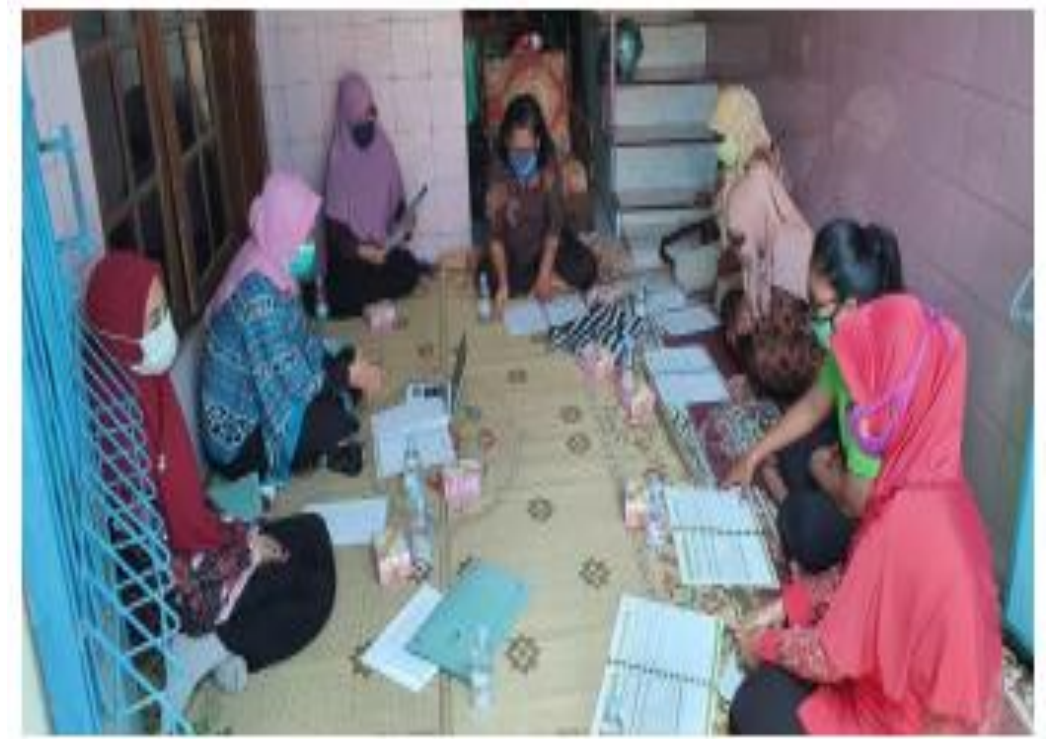

Gambar 2. Rangkaian Kegiatan Pengabdian Masyarakat

\section{KESIMPULAN DAN SARAN}

Kegiatan pengabdian masyarakat ini meningkatkan pengetahuan orang tua tentang penanganan kejang demam anak dengan kejang demam di rumah, serta meningkatkan kemampuan orang tua dalam penanganan kegawatdaruratan anak dengan kejang demam di rumah. Evidence based practice pada penanganan kegawatdaruratan anak dengan kejang demam di rumah dapat di lakukan atau sebagai penanganan pertama anak dengan kejang demam di rumah.

Kader, stakeholder puskesmas, masyarakat dapat menerapkan pendidikan kesehatan terstruktur dalam kegiatan pengabdian masyarakat dengan pendekatan HBM dalam upaya pencegahan dan penanganan kejam demam pada anak di rumah. Puskesmas, kader bersama dengan institusi pendidikan dapat bekerjasama dan berkolaborasi dalam pencegahan dan penanganan kejang demam pada anak di rumah.

\section{UCAPAN TERIMA KASIH}

Tim penulis mengucapkan terima kasih kepada Direktur Poltekkes Kemenkes Surakarta yang telah mendukung dan memfasilitasi kegiatan pengabdian masyarakat ini.

\section{DAFTAR RUJUKAN}

Adriani, R. B., Astuti, D. D., \& ... (2020). Stop tuberkulosis melalui pendekatan model information motivation and behavioral skills (IMB). ... (Jurnal Pengabdian Dan ..., 4(2), 195-204. 
Alqahtani, S. M. (2019). Perception and parent's knowledge about high body temperatures in children and treatment methods at home. World Family Medicine, 17(4), 4-10.

Ateşoğlu, M., İnce, T., Lüleci, D., Ergör, A., \& Aydın, A. (2018). Prevalence of febrile seizures in school-aged children: A community based survey in İzmir, Turkey. The Journal of Pediatric Research, 5(4), 208-213. https://doi.org/10.4274/jpr.29290

Barzegar, M., Valizadeh, S., Gojazadeh, M., Asghari Jafarabadi, M., Zamanzadeh, V., \& Shahbazi, S. (2016). The effects of two educational strategies on knowledge, attitude, concerns, and practices of mothers with febrile convulsive children. Thrita, 5(2). https://doi.org/10.5812/thrita.33411

Castellano, V. E., Talamona, N., Giglio, N. D., Sabbaj, L., \& Gentile, Á. (2020). Knowledge and management of fever in parents of children under 5 years of age at a children's hospital. Archivos Argentinos de Pediatria, 118(October 2018), 89-94. https://doi.org/10.5546/aap.2020.eng.89

Chiabi, A., Nguefack, S., Monkam, R. T., Enoh, J., Dongmo, F. N., Bilo’o, L. L., \& Mbonda, E. (2018). Practices of mothers towards infant seizures in Yaounde, Cameroon. The Journal of Medical Research, 4(2), 102-105. https://doi.org/10.31254/jmr.2018.4210

Dogahe, S. M. M., Pasha, A., Chehrzad, M., \& AtrkarRoshan, Z. (2018). The effect of education based on the Health Belief Model in mothers about behaviors that prevent febrile seizure in children. International Journal of Biomedicine and Public Health, 1(1), 23-29. https://doi.org/10.22631/ijbmph.2018.55452

Elbilgahy, A. A., \& Abd El Aziz, R. A. E. A. E. S. (2017). Effect of implementing an educational module on improving mothers knowledge, home management and attitude about febrile convulsion. Journal of Nursing Education and Practice, 8(3), 1. https://doi.org/10.5430/jnep.v8n3p1

Gundapu, G. R., Bhavani, M., Kiran, M. A., \& Kumar, N. (2017). Safety and prevention of febrile seizures in pediatrics, idenitify new symptoms, adverse effects, side effects, life style modifications, patient councelling, observing, monitoring. InternationalJournal of Medical Research and Pharmaceutical Sciences, 4(2), 110.

Hamaad, W. A., Hassan, W., \& Alseraty, H. (2019). Impacts of seizure care simulation intervention on mothers' of epileptic children efficiency, believes, anxiety and seizure care. American Journal of Nursing Research, 7(3), 293-300. https://doi.org/10.12691/ajnr-7-3-9

Kızılay, D. Ö., Kırdök, A. A., Ertan, P., Ayça, S., Demet, M. M., \& Polat, M. (2017). Information is power: An interventional study on parents of children with febrile seizures. 4(2), 53-58. 
Kumar, R., Khakha, D. C., Gulati, S., \& Kaushik, J. S. (2019). Impact of structured teaching program on the parent's knowledge of domiciliary management of seizure - A randomized controlled trial. Epilepsy and Behavior, 92(September 2015), 191-194. https://doi.org/10.1016/j.yebeh.2018.11.038

Laino, D., Mencaroni, E., \& Esposito, S. (2018). Management of pediatric febrile seizures. International Journal of Environmental Research and Public Health, 15(10). https://doi.org/10.3390/ijerph15102232

Pender, N. J., Murdaugh, C. L., \& Parsons, M. A. (2015). Health promotion in nursing practice (7th ed.). https://doi.org/10.1007/BF00841552

Rasyid, Z., Kusuma, D., Vita, C., \& Purba, G. (2019). Determinants of Fever Events in Toddlers Budhi Mulia Pekanbaru Mother and Child Hospital. Jurnal Epidiomologi Kesehatan Indonesia, 3(1), 1-6.

Rofiqoh, S., \& Isyti'aroh, I. (2018). Effort to reduce anxiety levels among mothers using febrile convulsions educational package. Belitung Nursing Journal, 4(4), 390-396. https://doi.org/10.33546/bnj.386

Sajadi, M., \& Khosravi, S. (2017). Mothers' experiences about febrile convulsions in their children: A qualitative study. International Journal of Community Based Nursing and Midwifery, 5(3), 284-291.

Salehi, B., Yousefichaijan, P., Safi-Arian, S., Ebrahimi, S., Mohammadbeigi, A., \& Salehi, M. (2016). The effect of simple febrile seizure on Attention Deficit Hyperactivity Disorder (ADHD) in children. International Journal of Pediatrics, 4(7), 2043-2049. https://doi.org/10.22038/ijp.2016.6927

Silverman, E. C., Sporer, K. A., Lemieux, J. M., Brown, J. F., Koenig, K. L., GauscheHill, M., ... Gilbert, G. H. (2017). Prehospital care for the adult and pediatric seizure patient: Current evidence-based recommendations. Western Journal of Emergency Medicine, 18(3), 419-436. https://doi.org/10.5811/westjem.2016.12.32066

Srinivasa, S., Anjum, S. K., Patel, S., S., H., \& G., B. (2018). Parental knowledge, attitude and practices regarding febrile convulsion. International Journal of Contemporary Pediatrics, 5(2), 515. https://doi.org/10.18203/23493291.ijcp20180546

Villarejo-Rodríguez, M. G., \& Rodríguez-Martín, B. (2020). Parents' and primary caregivers' conceptualizations of fever in children: A systematic review of qualitative studies. Nursing and Health Sciences, 22(2), 162-170. https://doi.org/10.1111/nhs.12639 